\title{
Influence of the Workpice Quality on the Cutting Tool Life when Gear Wheel are Machined
}

\section{Miroslav Zetek, Ivana Zetková}

Regional Technological Institute, Univerzity of West Bohemia, Univerzitni 8, 30614 Plzen,

Czech Republic, E-mail: mzetek@rti.zcu.cz, zetkova@rti.zcu.cz

The stability of the machining process is depending on the machined materials properties. But the material properties are influence by the heat treatment process and in this case it is forging. For these study three different company made the "same" forging process and then the material properties are evaluated and their influences on the cutting process were monitored. For the tests the steel DIN 18 CrNiMo 6-7 was used. This material is typically used for the gear wheels where the cutting tools by tool steel is used for the machining. So for the tests the mills from tool steel were used and during the machining the cutting tool life and cutting forces were monitored.

Keywords: Gear wheel, Material analysis, Cutting tool wear, Cutting tool life, Cutting forces

\section{Acknowledgement}

The present contribution has been prepared under project LO1502 'Development of the Regional Technological Institute' under the auspices of the National Sustainability Programme I of the Ministry of Education of the Czech Republic aimed at supporting research, experimental development and innovation.

\section{References}

[1] YOUNES RAMDANE, HAMZAOUI NACER, OUELAA NOUREDINE, DJEBALA ABDERRAZEK (2015). Perceptual study of the evolution of gear defects, Applied Acoustics 99 (2015) 60-67.

[2] GU, L., XU, J., LUO, S. (2016). The design of new cycloid gear with variable cross section and the research of end milling in five-axis machine tool, Manufacturing Technology, Volume 16 (3), 2016, pp. 497-502

[3] DUBOVSKA, R., MAJERIK, J. (2015). The Research Analysis of Surface Finish and Wear on the Special Tribological Device, Procedia Engineering 100 (2015) 730-736.

[4] SIECLA, R., LEGUTKO, S. (2012). Gear-shaper cutter with curvilinear side flank face, Manufacturing Technology, Volume 12, Issue 13, 2012

[5] ADIS J. MUMINOVIC, ISAD SARIC, NEDZAD REPCIC (2015). Numerical Analysis of Stress Concentration Factors, Procedia Engineering 100 (2015) 707-713.

[6] DUBOVSKA, R., JAMBOR, J., MAJERIK, J (2014). Qualitative Aspects of Machined Surfaces of High Strength Steels, Procedia Engineering 69 (2014) 646 - 654.

[7] BERÁNEK, L., KOLǍ̌ÍK, K. (2014). Surface integrity analysis of duplex steel by design of experiment approach, Procedia Engineering 69 (2014) 630 - 637.

[8] MORAVČÍKOVÁ, J. (2015). Cutting Material Influence on the Quality of the Machined Surface, Procedia Engineering 100 (2015) $328-333$.

[9] MARCO SORTINOA, SANDRO BELFIO, GIOVANNI TOTIS, ELSO KULJANIC, GIOVANNI FADELLI, Innovative Tool Coatings for Increasing Tool Life in Milling

[10] VOPÁT, T., PETERKA, J., ŠIMNA, V., KURUC, M. (2015). The Influence of Different Types of Copy Milling on the Surface Roughness and Tool Life of End Mills, Procedia Engineering 100 (2015) 868 - 876 